\title{
Evaluation of some biocontrol agents to control Thompson seedless grapevine powdery mildew disease
}

\author{
M. F. A. Ahmed
}

\begin{abstract}
This investigation aimed to evaluate the effect of some biocontrol agents against the powdery mildew of Thompson seedless grapevines. The study was carried out during the two successive seasons (2016 and 2017) at a private organic vineyard orchard located at El Beheira Governorate, Egypt. Uncinula necator (syn. Erysiphe necator) is a fungus that causes powdery mildew of grapevine. It causes severe loss in yield quantity and quality. Application of different biocontrol agents, e.g., Trichoderma harzianum, T. hamatum, T. viride, and their combinations, as well as the Blight stop (Trichoderma spp.), a commercial biocide and micronic sulfur, was an attempt to control the disease. The mixture of the three Trichoderma spp. showed the highest efficacy (80.16 and 89.95\%) of controlling the disease incidence and severity in the two seasons 2016 and 2017, respectively, followed by the treatment of Blight stop + micronic sulfur (77.12 and 84.02\%), while micronic sulfur showed the lowest effect (57.02 and 41.32\%). At all treatments, the yield was increased and the chemical characteristics, e.g., "total sugars, total soluble solids (TSS), total anthocyanin (\% in mg/100 g F.W.), and total phenols (mg/g betties as gallic acid equivalent)" of berries were improved. On the contrary, the percentage of total acidity was decreased at all treatments than in the control.
\end{abstract}

Keywords: Grapevine, Uncinula necator, Powdery mildew, Micronic sulfur, Biocontrol agents

\section{Background}

Grapevine (Vitis vinifera L.) is one of the most important commercial fruits grown in Egypt. It is considered one of the most widely cultivated crops in temperate, sub-tropical, and tropical regions of the world. Grapevine cultivation offers a great economic potential due to its higher yield and monetary returns owing to the export (Vinothini et al. 2014). Grapevine is subjected to the infection with powdery mildew, caused by Uncinula necator (Schwein.) Burrill. teleomorph of Oidium tuckeri Berk. Recently renamed Erysiphe necator Schwein and placed into the section Uncinula of the genus (Braun and Takamatsu 2000). Powdery mildew is a worldwide economically important fungal disease in the grapevine farms and the most enduring and widespread problem (Gadoury et al. 2012).

In Egypt, powdery mildew was found on different varieties of grapevine causing considerable losses in grape production (Saleh et al. 2007). The disease can be

Correspondence: mohamed_faah@yahoo.com

Central Lab. of Organic Agriculture, ARC, Giza, Egypt devastating on susceptible varieties under the proper environmental conditions. However, infection caused by this fungus develops at high humidity conditions, but not by free water (Sawant et al. 2017). The release of ascospores has always been associated with rainy periods, where cumulative rainfall ranged between 2 and $58.5 \mathrm{~mm}$. Therefore, rain is necessary for ascospore release that is a primary source of inocula (Jailloux et al. 1999).

Control of powdery mildew infections becomes a challenge with the limited chemical options available. Biological control of plant diseases, using microorganisms, is a very promising alternative to the extended use of fungicides. It has received a considerable attention as an alternative strategy (El-Rafai et al. 2003). Among the biological control agents, Trichoderma spp. are the most promising and effective biocontrol agents. Trichoderma afroharzianum Rifai showed a higher tolerance to fungicides commonly used in powdery mildew management (Sawant et al. 2017). 
Trichoderma spp., as antagonists, can control a wide range of microbes and their mechanism of mycoparasitism is much more complex, involves nutrient competition, hyperparasitism, antibiosis, space and cell wall degrading enzymes (Chet et al. 1997). Trichoderma harzianum is a cosmopolitan species that might be found in the ground and can be considered as an identical biocontrol agent for its ideal characteristics. This antagonist is very easy to be isolated and to be grown rapidly on any organic staff. $T$. harzianum acts through different mode of actions, i.e., mycoparasitism (Benhamoud and Chet 1993), production of antifungal (Robinson et al. 2009), also it owns an enzyme system that causes a destruction for the pathogens (Bolar et al. 2000). It also acts as inducer for resistance in treated plants against certain pathogen organs (Shoresh et al. 2010). It is also clear that it can grow within a wide range of temperature and other environmental conditions (Singh et al. 2010).

Mixing antagonists with each other (T. harzianum and T. viride) might lead to an antagonistic effect, consequently decrease efficacy of treatment (Robinson et al. 2009) or lead to synergistic effect and increase the efficacy (Latha et al. 2009). This increase or decrease is due to the harmony and compatibility factors among bioagents. Due to the wide variation in antagonism and biocontrol efficacies exhibited by naturally occurring isolates of Trichoderma, the first requirement for developing a successful biocontrol system is of a highly effective strain (Sawant et al. 2012).

The application of sulfur spray, at the rate of $600 \mathrm{~g} / 100 \mathrm{~L}$ on grape leaves, has shown most effective in that management of powdery mildew and improved the grape yield compared with untreated plants (Emmett et al. 2003). It works by killing the spores of powdery mildew, thus protecting the vines from new infections. It does not kill the fungus itself. The best use of sulfur, therefore, is to prevent vines from becoming infected, rather than to suppress infections once they have developed. Existing mature fungal colonies begins producing more spores a week after a sulfur spray is applied.

The present work aimed to evaluate different uses of bioagents (Trichoderma spp.) and/or their mixtures compared with a chemical treatment (micronic sulfur) against the powdery mildew of Thompson seedless grapevines under Egyptian field conditions, and their reflects on the vine growth, yield, and fruit quality.

\section{Materials and methods}

\section{Antagonistic microorganisms}

Different biocontrol agents, i.e., Trichoderma harzianum, $T$. hamatum, and $T$. viride were kindly obtained from the Central Lab. of Organic Agriculture, CLOA, ARC, Giza, Egypt.

\section{Commercial biofungicide (blight stop)}

The recommended biofungicide which consists of (Trichoderma spp. $30 \times 10^{6}$ ), obtained from CLOA, was used for comparison.

\section{Micronic sulfur}

The recommended fungicide micronic sulfur was used also as a comparison with the tested treatments. Manufacture by Kz, Egypt, consistence of Micronized Soreil/ Samark $70 \%$ wp sulfur.

\section{Preparations of the biocontrol agents}

Trichoderma harzianum, $T$. hamatum, and $T$. viride were prepared as follows: each of the antagonistic fungi was grown for 10 days at $25 \pm 2{ }^{\circ} \mathrm{C}$ on a liquid Gliotoxin fermentation (GF) medium under complete darkness conditions (Ahmed 2013). All cultures were individually blended in an electrical blender for $2 \mathrm{~min}$, used as suspension at concentration of $\left(30 \times 10^{6}\right.$ spores $\left./ \mathrm{ml}\right)$ with a dilution 1:100, and then mixed with 5\% Arabic gum and $5 \%$ potassium soap and wetting the leaves, using a sprayer to increase adhesive capacity and improve distribution of bioagent on the surface of treated plants for all preparations and blight stop the commercial biocide. Mixtures of the three Trichoderma spp. were mixed at the rate of $1: 1$.

\section{Field applications}

The study was conducted for two successive seasons (2016 and 2017) in a private vineyard, called Electricity Station Farm, which is registered at ECOA control body, as a full organic farm, under the code number A812, Wadi El Faregh, Wadi El-Natroun, El Beheira Governorate, Egypt to evaluate using organic products to reduce powdery mildew of Thompson seedless grapevines and their reflects on vine growth, fruits yield, quantity and quality. The chosen vines were 12 years old, grown in a sandy loam soil, spaced at $(1.5 \times 3.0 \mathrm{~m})$ apart and irrigated, using drip irrigation system, trained to bilateral cordon with spur pruning and trellised by the "Y" shape system. The vines were pruned at the end of January in both seasons according to Fawzi et al. (2010).

All vines received the same agricultural practices applied in the vineyard. Every five vines acted as a replicate and each three replicates were treated by $T$. harzianum, $T$. hamatum, $T$. viride, their combinations and blight stop were used as a suspension at the concentration of $\left(30 \times 10^{6}\right.$ spore $\left./ \mathrm{ml}\right)$ with a dilution of $(1: 100)$, while micronic sulfur was used at the rate of $(250 \mathrm{~g} / 100 \mathrm{~L})$. Arabic gum and potassium soap were added at (5\%) for each spray. Only distilled water was applied at the same period as control. Foliar sprays of the treatments were applied at a regular interval and repeated two times every 
other week. All treatments received the same normal agricultural practice till harvest in May.

\section{Plant parameters adopted to evaluate the treatments Disease assessment}

For powdery mildew assessment, the evaluation on leaves was carried out 15 days post the last application.

$\%$ Disease incidence (DI) was determined according to the formula:

$$
\mathrm{DI} \%=\frac{\text { Number } \text { of infected leaves }}{\text { Total nostudied leaves }} \times 100
$$

The disease severity was recorded immediately pre each spray application and 7 days post the last spray. It was rated as a $0-5$ scale, where $0=$ no infection, $1=1-$ $10 \%$ leaf area infected with powdery mildew, $2=11-$ $25 \%, 3=26-50 \%, 4=51-75$, and $5=76-100 \%$ (Horsfall and Heuberger 1942). The ratings were converted to percent disease index (PDI), using the formula given by Wheeler (1969):

D.S.I\% $=\frac{\sum(\mathrm{nxv})}{\mathrm{ZN}} \times 100$, where D.S.I $=$ disease severity index, $n=$ number of leaves in each category, $v=$ numerical value of each category, $z=$ numerical value of highest category and $N=$ total number of leaves in the sample.

In addition to plant height, no. of leaves/plant, fresh weight/plant, and onion bulb yield as $\mathrm{kg} / \mathrm{plot}$ was weighted at the end of each season.

\section{Yield ( $\mathrm{kg} /$ vine)}

At harvesting, when TSS\% of berries reached about (16-17\%) in control, 6 clusters/vine were weighted and an average cluster weight was multiplied by the number of clusters/vine to calculation average of yield/vine.

\section{Biochemical characteristics (properties)}

Representative random samples of six bunches/vine were harvested at maturity, when total soluble solids (TSS) reached about (16-17\%) according to Tourky et al. (1995).

All bio-chemical analysis were conducted at the Central Lab. of Organic Agriculture; CLOA; Agricultural Research Center, ARC; Giza Governorate, Egypt.

1. Total soluble solids content (TSS \%): fresh preparation of the berry juice samples was used for determination of the total soluble solids (TSS), using a hand refractometer (Model BX-1 and Brix $0-32 \%)$.

2. Total acidity percentage was determined according to A.O.A.C (2003).

3. TSS/acid ratio was calculated by dividing the percentage of TSS on the value of total acidity.
4. Total sugars (\%) were determined according to Sadasivam and Manickam (1996)

5. Total anthocyanin: total anthocyanin of berries skin (\% in $\mathrm{mg} / 100 \mathrm{~g}$ fresh weight) was determined by using the spectrophotometer at wave length of $535 \mathrm{~mm}$, according to the method of Husia et al. (1965).

6. Total phenols: total phenols ( $\mathrm{mg} / \mathrm{g}$ berries as gallic acid equivalent/g FW) was based on Folin-

Ciocalteau reagent (Zieslin and Ben-Zaken 1993). Changes in sugar and phenol contents in infected table grapes, 35 days post the storage time were considered. Determinations of phenolic compounds were calorimetrically determined by a spectrophotometer at $760 \mathrm{~nm}$ as described by Snell and Snell (1953).

\section{Statistical analysis}

The complete randomized block design was adopted for the experiment. Data were subjected to statistical analysis and compared according to the least significant difference (LSD) as mentioned by Snedecor and Cochran (1989). Averages were compared using the new LSD values at $5 \%$ level.

\section{Results and discussion}

Evaluation of the biocontrol potential of antagonistic isolates in vineyard

All the tested biological control treatments (Trichoderma harzianum "T. s.", T. viride "T. v.", T. hamatum "T. h."), their combinations (T. harzianum $+T$. viride); (T. harzianum + T. hamatum $) ;(T$. viride $+T$. hamatum); (T. harzianum $+T$. viride $+T$. hamatum $)$, and the commercial preparation, blight stop $\{(T . s .+T . v .+T . h$. + M. s.) and micronic sulfur (MS) alone\} significantly reduced the powdery mildew rate on Thompson grapevine disease parameters (incidence and severity) in 2016 and 2017 growing seasons than in the control treatment (Table 1).

Significant differences were found also among the bioagents vital treatments. The mixture of T. harzianum $+T$. viride $+T$. hamatum showed the highest efficacy (80.16 and $89.95 \%)$, followed by blight stop + micronic sulfur (77.12 and $84.02 \%)$ in controlling disease incidence and severity during the two seasons 2016 and 2017, respectively. On the other hand, micronic sulfur showed the respective lowest efficacy (57.02 and 41.32\%) in controlling the disease.

In vivo, the results may be explained according to the dual effect of the bioagents, which produce growth regulators in addition to the chemical effect of antioxidants, which plays a clear role in improving plant physiology, metabolism (Sawant and Sawant (2010) and induce systemic resistance (ISR) (Compant and Mathieu 2016). 
Table 1 Efficacy of different antagonists on powdery mildew of Thompson grapevine disease parameters (incidence and severity) under Egyptian field conditions during 2016 and 2017 seasons

\begin{tabular}{|c|c|c|c|c|c|c|c|c|}
\hline \multirow[t]{2}{*}{ Tested antagonists } & \multicolumn{4}{|c|}{ Disease incidence \% } & \multicolumn{4}{|c|}{ Disease severity \% } \\
\hline & 2016 & 2017 & Mean & Efficacy* & 2016 & 2017 & Mean & Efficacy* \\
\hline T. harzianum (T.s.) & 17.1 & 17.3 & 17.2 & 70.19 & 6.1 & 6.5 & 6.3 & 71.23 \\
\hline T. viride (T.v.) & 18.3 & 18.5 & 18.4 & 68.11 & 8.7 & 8.9 & 8.8 & 59.82 \\
\hline T. hamatum (T.h.) & 22.4 & 22.6 & 22.5 & 61.01 & 11.3 & 11.5 & 11.4 & 47.95 \\
\hline$T . S+T . v$. & 14.1 & 14.6 & 14.35 & 75.13 & 4.4 & 4.6 & 4.5 & 79.45 \\
\hline T.s + T.h. & 16.2 & 16.6 & 16.4 & 71.58 & 5.5 & 5.8 & 5.65 & 74.20 \\
\hline$T . v+T . h$. & 21.3 & 21.7 & 21.5 & 62.74 & 9.6 & 10.0 & 9.8 & 55.25 \\
\hline T.S. + T.V. + T.h. & 11.3 & 11.6 & 11.45 & 80.16 & 2.1 & 2.3 & 2.2 & 89.95 \\
\hline Micronic sulfur (MS) & 24.4 & 25.2 & 24.8 & 57.02 & 12.7 & 13.0 & 12.85 & 41.32 \\
\hline Blight stop (T.s. + T.v. + T.h. $)+\mathrm{MS}$ & 13.1 & 13.3 & 13.2 & 77.12 & 3.3 & 3.7 & 3.5 & 84.02 \\
\hline Control untreated & 57.1 & 58.3 & 57.7 & 00.00 & 21.6 & 22.2 & 21.9 & 00.00 \\
\hline LS D at 0.05 & 1.60 & 0.09 & & & 0.11 & 0.08 & & \\
\hline
\end{tabular}

* \% Efficacy $=(($ control-treatment $) /$ control $) \times 100$

The potential of Trichoderma spp. for controlling the plant pathogenic fungi have been known to include direct effects upon target fungi via competition, mycoparasitism, and antibiosis as their primarily mechanisms (Ahmed 2013). Matei and Matei (2008) explained this protection effect as antibiosis action occurred in court of infection. Some other investigators reported changes in plant physiology and chemical components in plants treated with these bioagents (Hafez et al. 2012). Also, Trichoderma spp. are reported to produce antifungal substances such as Endo chitinase, beta-glucosidase, alpha-1,3-glucanase (Monteiro et al. 2011), and trichodermin (Balode 2010); meanwhile, the other isolates compete for space or nutrients. Mixing different isolates increase the scope of mode of action consequently increase efficacy of the treatment.

\section{Effect of the tested antagonists on yield and its components}

The yield and its components were significantly affected by the applied treatments in both seasons (Table 2). The mixture of $T$. harzianum $+T$. viride $+T$. hamatum caused the highest significant increase in the yield values (19.5 and $19.7 \mathrm{~kg} /$ vine) during 2016 and 2017 growing seasons, respectively than in the control. On the other hand, micronic sulfur treatment recorded the lowest effect (13.4 and $13.6 \mathrm{~kg} / \mathrm{vine})$ in the two seasons, respectively. This observation could be attributed to the synergistic dual effects due to the bioagents, which produce growth regulators (Karlidag et al. 2012), in addition to their effect as resistant inducer (Compant and Mathieu 2016). This improvement led to an increase in yield and dry matter.

Table 2 Effect of different antagonists on powdery mildew of Thompson grapevine yield under Egyptian field conditions during 2016 and 2017 seasons

\begin{tabular}{|c|c|c|c|c|c|c|}
\hline \multirow[t]{2}{*}{ Tested antagonists } & \multicolumn{2}{|c|}{ No. of clusters/vine } & \multicolumn{2}{|c|}{ Cluster weight (g) } & \multicolumn{2}{|c|}{ Yield/vine (kg) } \\
\hline & 2016 & 2017 & 2016 & 2017 & 2016 & 2017 \\
\hline T. harzianum (T.S.) & 25 & 26 & 652 & 635 & 16.3 & 16.5 \\
\hline T. viride (T.v.) & 24 & 25 & 650 & 632 & 15.6 & 15.8 \\
\hline T. hamatum (T.h.) & 22 & 23 & 659 & 639 & 14.5 & 14.7 \\
\hline T.S. + T.V. & 27 & 28 & 670 & 654 & 18.1 & 18.3 \\
\hline T.s. + T.h. & 26 & 27 & 662 & 648 & 17.2 & 17.5 \\
\hline T.v. + T.h. & 23 & 24 & 657 & 638 & 15.1 & 15.3 \\
\hline T.S. + T.V. + T.h. & 28 & 29 & 696 & 679 & 19.5 & 19.7 \\
\hline Micronic sulfur (MS) & 20 & 21 & 670 & 648 & 13.4 & 13.6 \\
\hline Blight stop (T.s. + T.v. + T.h. $)+\mathrm{MS}$ & 29 & 30 & 700 & 683 & 20.3 & 20.5 \\
\hline Control untreated & 17 & 18 & 482 & 483 & 8.2 & 8.7 \\
\hline LS D at 0.05 & 0.80 & 0.55 & 1.14 & 1.06 & 1.78 & 0.24 \\
\hline
\end{tabular}


Table 3 Effect of different antagonists and micronic sulfur on total soluble solids (TSS), total acidity, and TSS/acid ratio of Thompson grapevine under Egyptian field conditions during 2016 and 2017 seasons

\begin{tabular}{|c|c|c|c|c|c|c|}
\hline \multirow[t]{2}{*}{ Tested antagonists } & \multicolumn{2}{|c|}{ Total soluble solids (TSS \%) } & \multicolumn{2}{|c|}{ Total acidity (\%) } & \multicolumn{2}{|c|}{ TSS/acid ratio } \\
\hline & 2016 & 2017 & 2016 & 2017 & 2016 & 2017 \\
\hline T. harzianum (T.s.) & 15.7 & 15.8 & 0.61 & 0.62 & 25.74 & 25.48 \\
\hline T. viride (T.v.) & 15.2 & 15.3 & 0.62 & 0.63 & 24.52 & 24.29 \\
\hline T. hamatum (T.h.) & 14.1 & 14.3 & 0.66 & 0.67 & 21.36 & 21.34 \\
\hline T.S. + T.v. & 16.7 & 16.9 & 0.57 & 0.58 & 29.30 & 29.14 \\
\hline T.S. + T.h. & 16.1 & 16.4 & 0.59 & 0.60 & 27.29 & 27.33 \\
\hline T.V. + T.h. & 14.2 & 14.4 & 0.64 & 0.65 & 22.19 & 22.15 \\
\hline T.S. + T.V. + T.h. & 17.3 & 17.6 & 0.52 & 0.53 & 33.27 & 33.21 \\
\hline Micronic sulfur (MS) & 13.7 & 13.9 & 0.68 & 0.69 & 20.15 & 20.14 \\
\hline Blight stop (T.s. + T.v. + T.h. $)+\mathrm{MS}$ & 18.1 & 18.2 & 0.50 & 0.51 & 36.20 & 35.69 \\
\hline Control untreated & 11.1 & 11.2 & 0.74 & 0.76 & 15.00 & 14.74 \\
\hline LS D at 0.05 & 0.06 & 0.07 & 0.01 & 0.04 & 0.19 & 0.28 \\
\hline
\end{tabular}

\section{Effect of the tested antagonists on chemical characteristics of berries}

All treatments led to increases in all the tested parameters of fruits (total soluble solids "TSS" and TSS/acid ratio) and decreases in the percentage of total acidity compared with micron sulfur and control treatments in both seasons of the study (Table 3). These increases might be due to the healthy and vigor growth of treated plants, which improves photosynthesis and other biochemical activities in plant physiology consequently increases TSS and TSS/acid ratio (Fawzi et al. 2010). The lowest values of acidity $(0.50$ and $0.51 \%)$ were obtained by spraying the blight stop + micronic sulfur, followed by the mixture of $T$. harzianum $+T$. viride + T. hamatum (0.52 and $0.53 \%)$, respectively. Micron sulfur recorded the highest values $(0.68$ and $0.69 \%)$ of acidity than the control treatment in the two seasons, 2016 and 2017, respectively.
These synergistic effects might be due to the dual effect of the bioagents, which produce growth regulators in addition to their effect as resistant inducer (Constantinescu et al. 2009). Bioagents not only affect outer surface plant but also affect plant metabolism leading to changes in plant components (Hafez et al. 2012) and improving plant growth (Kloepper et al. 2004). Tronsmo et al. (1993) reported that T. harzianum isolates produce chitinase and 1,3 gluconase enzymes, which are responsible for dissolving cell wall of the pathogenic fungi, then grow and consume its inner contents causing destruction of the pathogen's cells.

Spraying Thompson grapevine in all applied treatments used in this study, separately and/or their mixtures, caused significant increases in chemical characteristics of "total sugars, total anthocyanin, and total phenols" in both seasons 2016 and 2017 compared with the untreated plants (Table 4). The treatment of blight stop + micronic

Table 4 Effect of different antagonists and micronic sulfur on total (sugars, anthocyanin, and phenols) of Thompson grapevine under Egyptian field conditions during 2016 and 2017 seasons

\begin{tabular}{|c|c|c|c|c|c|c|}
\hline \multirow[t]{2}{*}{ Tested antagonists } & \multicolumn{2}{|c|}{ Total sugars (\%) } & \multicolumn{2}{|c|}{ Total anthocyanin (\%) } & \multicolumn{2}{|c|}{ Total phenols (mg/g betties as gallic acid equivalent) } \\
\hline & 2016 & 2017 & 2016 & 2017 & 2016 & 2017 \\
\hline T. harzianum (T.s.) & 17.21 & 17.25 & 35.10 & 35.20 & 432.50 & 435.20 \\
\hline T. viride (T.v.) & 16.72 & 16.78 & 34.10 & 34.20 & 423.10 & 429.60 \\
\hline T. hamatum (T.h.) & 15.20 & 15.30 & 32.50 & 32.72 & 367.10 & 376.00 \\
\hline T.s. + T.v. & 18.11 & 18.20 & 37.19 & 37.21 & 532.10 & 535.20 \\
\hline T.S. + T.h. & 17.60 & 17.70 & 36.50 & 36.90 & 470.60 & 478.80 \\
\hline T.v. + T.h. & 16.20 & 16.30 & 33.48 & 33.80 & 389.50 & 393.10 \\
\hline T.S. + T.V. + T.h. & 18.70 & 18.80 & 37.08 & 37.15 & 542.50 & 542.66 \\
\hline Micronic sulfur (MS) & 14.22 & 14.30 & 30.11 & 31.09 & 287.90 & 304.10 \\
\hline Blight stop $($ T.S. + T.V. + T.h. $)+\mathrm{MS}$ & 19.60 & 20.10 & 38.50 & 39.10 & 593.37 & 593.50 \\
\hline Control untreated & 11.48 & 11.85 & 21.86 & 21.93 & 252.20 & 258.10 \\
\hline LS D at 0.05 & 0.04 & 0.02 & 0.03 & 0.06 & 0.98 & 0.83 \\
\hline
\end{tabular}


sulfur gave the highest values in total sugars, total anthocyanin, and total phenols in berry skin compared with the other treatments, followed by the mixture of $T$. harzia$n u m+T$. viride $+T$. hamatum compared with the control treatment in 2016 and 2017 seasons, respectively. While spraying Thompson grapevine with micronic sulfur alone gave the lowest values in chemical characteristics this regards (Table 4).

On the other hand, spraying Thompson grapevine for controlling the powdery mildew disease, using different treatments, was accompanied by protecting the clusters from fruit rots, which reflects in decreasing fruit dropping and succeeds in gaining harvested clusters and high yield. This regime of treatments increased photosynthesis, consequently the amount of sugars, anthocyanin, and phenols and lead eventually to a good yield. This increase in yield may be due to a vigor growth of healthy plants, in addition, to growth regulators, produced by Trichoderma spp. and improved biochemical metabolism in the treated plants (Sawant and Sawant 2010).

\section{Conclusion}

Evaluations of different biocontrol agents, namely Trichoderma harzianum, T. hamatum, T. viride, alone or in combinations as well as with the blight stop, a commercial (Trichoderma spp.) biocide and the micronic sulfur, in reducing powdery mildew infection on grapevine were carried out under Egyptian field conditions. All vital bioagents' treatments significantly reduced disease parameters "incidence and severity" compared with micronic sulfur and control in the two seasons, 2016 and 2017. The yield was increased in all treatments, as well as improved the biochemical characteristics "total sugars, total soluble solids (TSS), total anthocyanin (\% in $\mathrm{mg} / 100 \mathrm{~g}$ fresh weight), and total phenols ( $\mathrm{mg} / \mathrm{g}$ betties as gallic acid equivalent)" of berries. On the contrary, all treatments decreased the percentage of total acidity. So, the results may support the new trend of using biocontrol agents and their combinations for control powdery mildew disease in grapevine orchards in Egypt.

\section{Acknowledgements}

Not applicable.

\section{Funding}

The publication costs for Egyptian Journal of Biological Pest Control are covered by Specialized Presidential Council for Education and Scientific Research (Government of Egypt) so authors do not need to pay an articleprocessing charge.

\section{Availability of data and materials}

All data and material which generated or analyzed during this study are available as reference by other researcher.

\section{Author's contribution}

Majority contribution for the whole article belongs to the author. The author read and approved the final manuscript.
Ethics approval and consent to participate

Not applicable.

\section{Consent for publication}

Not applicable.

Competing interests

The author declares that he has no competing interests.

\section{Publisher's Note}

Springer Nature remains neutral with regard to jurisdictional claims in published maps and institutional affiliations.

Received: 11 September 2018 Accepted: 6 November 2018

Published online: 29 November 2018

\section{References}

A.O.A.C (2003) Association of Official Agricultural Chemists, 16th edn. Benjamin Franklin station, Washington, D.C, pp 490-510

Ahmed MFA (2013) Studies on non-chemical methods to control some soil borne fungal diseases of bean plants Phaseolus vulgaris L. Ph.D. Thesis. Faculty of Agriculture, Cairo Univ, Giza, Egypt, p 137

Balode A (2010) Effect of tricodermin, biological product against Botrytis in horticultural crops. Acta Hortic 877:1583-1588

Benhamoud W, Chet I (1993) Hyphal interaction between Trichoderma and gold cytochemistry of the mycoparasitic process. Phytopathology 83:1062-1071

Bolar JP, Norelli JL, Wong KW, Hayes CK, Harman QE, Aldwinckle HS (2000) Expression of endochitinase from Trichoderma harzianumin transgenic apple increases resistance to apple scab and reduces vigor. Phytopathology 90:72-77

Braun U, Takamatsu S (2000) Phylogeny of Erysiphe, Microsphaera, Uncinula (Erysiphe) and Cystotheca, Podosphaera, Sphaerotheca (Cystotheceae) inferred from rDNA ITS sequences - some taxonomic consequences. Schlechtendalia 4:1-33

Chet I, Inbar J, Hadar I (1997) In: Wicklow DT, Soderstorm B (eds) Fungal antagonists and mycoparasites. In: the mycota IV: environmental and microbial relationships, pp 165-184

Compant S, Mathieu F (2016) Biocontrol of major grapevine diseases: leading research. CABI Publishing, CABI, p 240

Constantinescu F, Voshol G, Bloemberg G (2009) Mechanisms involved in biocontrol activity of $B$. subtilis B49b against Fusarium oxysporum f. sp. radicislycopersici. IOBCMPRS Bulletin 43:113-116

El-Rafai IM, Susan MW, Omaima AA (2003) Biocontrol of some tomato diseases using some antagonistic microorganisms. Pak J Biol Sci 6(4):399-406

Emmett RW, Magarey PA, Wicks TJ, Hitch C (2003) Strategic use of sulphur in integrated pest and disease management programs for grapevines. Final report to the Grape and Wine Research and Development Corporation, project DAV 98/1, Department of Primary Industries, Victoria, p 220

Fawzi MIF, Shahin MFM, Kandil EA (2010) Effect of bud load on bud behavior, yield, cluster characteristics and some biochemical contents of the cane of crimson seedless grapevines. J Am Sci 6(12):187-194 (ISSN: 1545-1003)

Gadoury DM, Cadle-Davidson L, Wilcox WF, Dry IB, Seem RC, Milgroom MG (2012) Grapevine powdery mildew (Erysiphe necator): a fascinating system for the study of the biology, ecology and epidemiology of an obligate biotroph. Mol Plant Pathol 13(1):1-16

Hafez EE, Balbaa MM, Kabeil SS, El-Saadani MA, Ahmed SA (2012) Molecular studies on the biocontrol effect of Trichoderma viride and Bacillus subtilis on Fusarium oxysporum and Rhizoctonia solani infected tomato plants. World Appl Sci J 19(1):89-99

Horsfall JG, Heuberger JW (1942) Measuring magnitude of a defoliation disease in tomatoes. Phytopathology 32:226-232

Husia CL, Luh BS, Chichester CD (1965) Anthocyanin in free stone peach. J Food Sci 30:5-12

Jailloux F, Willocquet L, Chapuisand L, Froidefond G (1999) Effect of weather factors on the release of ascospores of Uncinula necator, the cause of grape powdery mildew, in the Bordeaux region. Can J Bot 77:1044-1051

Karlidag H, Esitken A, Yildirim E, Donmez MF, Turan M (2012) Effects of plant growth promoting bacteria on yield, growth, leaf water content, membrane permeability, and ionic composition of strawberry under saline conditions. J Plant Nutr 34(1):34-45 
Kloepper JW, Choongmim RYU, Zhang SA (2004) Induced systemic resistance and promotion of plant growth by Bacillus spp. Phytopathology 94(11): 1259-1266

Latha P, Ragupathi ANT, Samiyappan RV (2009) Antimicrobial activity of plant extracts and induction of systemic resistance in tomato plants by mixtures of PGPR strains and Zimmu leaf extract against Alternaria solani. Biol Control 50(2):85-93

Matei GM, Matei S (2008) Research on isolation, characterization and testing the interaction between Trichoderma harzianum and Botrytis cinerea for biological control of gray mold in strawberry. Horticultura 51:653-657

Monteiro S, Grondona LM, Llobell I, Monte A (2011) In vitro antifungal activity of Trichoderma harzianum, T. longibrachiatum, T. asperellum and T. atroviride against Botrytis cinerea to strawberry. Bull OILB/SROP 25(10):253-256

Robinson LM, Jeger J, Xiangming P (2009) Management of strawberry gray mold using mixtures of biocontrol agents with different mechanisms of action. Biocontrol Sci Tech 19:1051-1065

Sadasivam S, Manickam A (1996) Biochemical Method, 2nd edn. New age international, (p) Itd. Publisher, New Delhi, pp 179-186

Saleh MMS, Ashour NE, MH E-s, El-Naggar MAA (2007) Foliar sprays of potassium dihydrogen phosphate and their impact on yield, fruit quality and controlling powdery mildew disease of Thompson seedless grapevines. J Agric Environs Sci 2(2):133-140

Sawant IS, Rajguru YR, Salunkhe VP, Wadkar PN (2012) Evaluation and selection of efficient isolates of Trichoderma species from diverse locations in India for biological control of anthracnose disease of grapes. J Biol Control 26:144-154

Sawant IS, Wadkar PN, Ghule SB, Rajguru YR, Salunkhe VP, Sawant SD (2017) Enhanced biological control of powdery mildew in vineyards by integrating a strain of Trichoderma afroharzianum with sulphur. Biol Control 114:133-143

Sawant SD, Sawant IS (2010) Improving shelf life of grapes by pre-harvest treatment with Trichoderma harzianum 5R. J Eco-friendly Agric 5:179-182

Shoresh M, Harman GE, Mastouri F (2010) Induced systemic resistance and plant responses to fungal biocontrol agents. Annu Rev Phytopathol 48:21-43

Singh V, Singh PN, Yadav RL, Awasthi SK, Singh RK, Duttamajumder SK (2010) Increasing the efficacy of Trichoderma harzianum for nutrient uptake and control of red rot in sugarcane. J Hortic For 2(4):66-71

Snedecor GW, Cochran WG (1989) Statistical Methods, 8th edn. lowa State Univ. Press, Ames, p 503

Snell FD, Snell CT (1953) Colorimetric methods of analysis, vol III. D. Van Nostr and Company Inc., Toronto, p 606

Tourky MN, El-Shahat SS, Rizk MH (1995) Evaluation of some new grape cultivars in relation to growth, yield, berry quality and storage life. J Agric Sci, Mansoura Univ 20(12):5153-5167

Tronsmo A, Klemsdal SS, Hayes CK, Lorito M, Harman GF (1993) The role of hydrolytic enzymes produced by Trichoderma harzianum in biological control of plant diseases. Found Biochem Indust Ferme Nuation Res, Helsiniki 8:159-169

Vinothini K, Ahiladevi P, Prakasam V (2014) Evaluation of bio-efficacy of new fungicide molecule_UPF 509 (Azoxystrobin 8.3 w/w +Mancozeb64.75 W/w) and biocontrol agents against powdery mildew of grapes. Pest Management in Horticultural. Ecosystems 20(1):75-79

Wheeler BEJ (1969) An introduction to plant disease. Wiley, London, p 301

Zieslin N, Ben-Zaken R (1993) Peroxidase activity and presence of phenolic substances in peduncles of rose flowers. Plant Physiol Biochem 31:333-339

\section{Submit your manuscript to a SpringerOpen ${ }^{\circ}$ journal and benefit from:}

- Convenient online submission

- Rigorous peer review

- Open access: articles freely available online

- High visibility within the field

- Retaining the copyright to your article

Submit your next manuscript at $\boldsymbol{\nabla}$ springeropen.com 